\title{
Molecular Pathology of Well-Differentiated Pulmonary and Thymic Neuroendocrine Tumors: What Do Pathologists Need to Know?
}

\author{
Marco Volante $^{1} \cdot$ Ozgur Mete $^{2} \cdot$ Giuseppe Pelosi $^{3} \cdot$ Anja C. Roden $^{4} \cdot$ Ernst Jan M. Speel $^{5} \cdot$ Silvia Uccella $^{6}$
}

Accepted: 21 January 2021 / Published online: 27 February 2021

(c) The Author(s) 2021

\begin{abstract}
Thoracic (pulmonary and thymic) neuroendocrine tumors are well-differentiated epithelial neuroendocrine neoplasms that are classified into typical and atypical carcinoid tumors based on mitotic index cut offs and presence or absence of necrosis. This classification scheme is of great prognostic value but designed for surgical specimens, only. Deep molecular characterization of thoracic neuroendocrine tumors highlighted their difference with neuroendocrine carcinomas. Neuroendocrine tumors of the lung are characterized by a low mutational burden, and a high prevalence of mutations in chromatin remodeling and histone modification-related genes, whereas mutations in genes frequently altered in neuroendocrine carcinomas are rare. Molecular profiling divided thymic neuroendocrine tumors into three clusters with distinct clinical outcomes and characterized by a different average of copy number instability. Moreover, integrated histopathological, molecular and clinical evidence supports the existence of a grey zone category between neuroendocrine tumors (carcinoid tumors) and neuroendocrine carcinomas. Indeed, cases with well differentiated morphology but mitotic/Ki-67 indexes close to neuroendocrine carcinomas have been increasingly recognized. These are characterized by specific molecular profiles and have an aggressive clinical behavior. Finally, thoracic neuroendocrine tumors may arise in the background of genetic susceptibility, being MEN1 syndrome the well-defined familial form. However, pathologists should be aware of rarer germline variants that are associated with the concurrence of neuroendocrine tumors of the lung or their precursors (such as DIPNECH) with other neoplasms, including but not limited to breast carcinomas. Therefore, genetic counseling for all young patients with thoracic neuroendocrine neoplasia and/or any patient with pathological evidence of neuroendocrine cell hyperplasia-to-neoplasia progression sequence or multifocal disease should be considered.
\end{abstract}

Keywords Neuroendocrine tumor $\cdot$ Carcinoid $\cdot$ Lung $\cdot$ Thymus $\cdot$ Molecular $\cdot$ Germline variants $\cdot$ MEN1 $\cdot$ RAD5A1C . DIPNECH

Marco Volante

marco.volante@unito.it

1 Department of Oncology, University of Turin, Turin, Italy

2 Departments of Pathology, University Healthy Network and University of Toronto, Toronto, Canada

3 Department of Oncology and Hemato-Oncology, University of Milan, Milan, Italy

4 Department of Laboratory Medicine and Pathology, Mayo Clinic Rochester, Rochester, MN, USA

5 Department of Pathology, GROW-School for Oncology and Developmental Biology, Maastricht University Medical Center, Maastricht, Netherlands

6 Dept. of Medicine and Surgery, University of Insubria, Varese, Italy

\section{Introduction}

Pulmonary neuroendocrine tumors (pulmonary carcinoid tumors) are well-differentiated epithelial neuroendocrine neoplasms that represent about $25 \%$ of all neuroendocrine neoplasms [1]. Unlike gastro-entero-pancreatic neuroendocrine tumors, pulmonary neuroendocrine tumors are diagnosed in the vast majority as early-stage disease. Lymph node involvement is present in about $20 \%$ of cases [2]. Stage III and stage IV diseases are encountered in about $10 \%$ of patients, each $[3,4]$. Thymic neuroendocrine tumors represent less than $5 \%$ of all thymic and mediastinal neoplasms and $0.4 \%$ of all neuroendocrine tumors. In general, thymic neuroendocrine tumors behave more aggressively than pulmonary neuroendocrine tumors, they are frequently metastatic, and 5-year survival is not reached 
in approximately 50\% [5]. Patients with these tumors are typically symptomatic, often secrete ectopic hormones (e.g., ACTH in $40 \%$ of tumors) and, like neuroendocrine tumors of the lung, secrete circulating biomarkers such as chromogranin A and 5-HIAA (metabolite of serotonin).

\section{Histopathological Classification}

World Health Organization (WHO) classification of thoracic tumors categorizes neuroendocrine tumors of the lung and thymus as typical ( $<2$ mitoses per $2 \mathrm{~mm}^{2}$ and no necrosis) and atypical (2-10 mitoses per $2 \mathrm{~mm}^{2}$ and/or necrosis) [6]. Tumor histology is one of the most powerful predictors of aggressive behavior in lung and thymic carcinoids. In fact, atypical carcinoid histology is an independent variable of adverse prognosis even in lung cases at the metastatic stage [7]. However, this classification scheme has been designed for resected primary tumors to predict the risk of recurrence or metastasis, whereas the clinical impact of these categories in metastatic setting is undetermined. Indeed, mitotic index cut off values per se have been recently called into question in a large series of over 700 well-differentiated lung neuroendocrine tumors [8]. Furthermore, the impact of Ki-67 labeling index as an adjunct in the subclassification of pulmonary carcinoids into distinct prognostic subgroups has been a matter of long debate $[9,10]$. Even recently, models that combine histology and proliferation index evaluation have been proposed [11], although not reaching a consensus that allows a definitive clinical application.

\section{The Grey Zone Between Thoracic Neuroendocrine Tumors and Neuroendocrine Carcinomas}

As a matter of fact, several pathological and clinical evidences suggest that typical and atypical carcinoid tumors should not be considered as distinct histotypes; they rather represent a unique group of lesions, the prognosis of which is driven by the presence or absence of a set of pathological features of aggressiveness. Moreover, the border between neuroendocrine tumor groups and thoracic neuroendocrine carcinomas (especially with large cell neuroendocrine carcinoma) is not clear cut, and a grey zone where morphology does not fully match with proliferation has been recognized. On the one side, a growing body of studies indicates that a subset of lung neuroendocrine tumors that are classified as pulmonary carcinoids based on mitotic index (therefore not above 10 mitotic figures in $2 \mathrm{~mm}^{2}$ ) have a significantly higher $\mathrm{Ki}-67$ proliferation rate than the mean of overall carcinoid tumors $[12,13]$. These cases, although maintaining a well differentiated morphology, have Ki-67 proliferation index close to large-cell neuroendocrine carcinomas and display a more aggressive clinical behavior than those with lower proliferative rates, irrespective of the carcinoid histotype assessed by the WHO classification [14, 15] (Fig. 1). On the other side, some lung neuroendocrine neoplasms classified as large-cell neuroendocrine carcinomas based on the high mitotic rate maintain a well-differentiated morphology, with a well-preserved organoid structure, focal necrosis-if present—and inconspicuous nucleoli [16]. These tumors, apart from classification issues, raise also the possibility of a direct progression from neuroendocrine tumors to neuroendocrine carcinomas. Although rarely demonstrable in the clinical practice [17], this possibility has been hypothesized based on clinical and molecular data [18].

Similar to neuroendocrine tumors elsewhere, the morphologic classification alone may fail to capture the heterogeneous spectrum of thymic neuroendocrine neoplasms. One of the best examples is the occurrence of thymic neuroendocrine tumors that show morphologic features of an atypical carcinoid but have a mitotic activity that is over 10 mitoses per $2 \mathrm{~mm}^{2}$ [19, 20] (Fig. 2). Similar to neuroendocrine tumors of the lung, limited evidence suggests that the morphologic classification of thymic neuroendocrine tumors might not accurately predict the outcome of all of these tumors. Specifically, there appears to be overlap between atypical carcinoid tumors and largecell neuroendocrine carcinomas.
Fig. 1 Atypical pulmonary carcinoid with high proliferation index. A well-circumscribed lung lesion (a) with spindle cell morphology - well differentiated - with mitotic index of 5 per $2 \mathrm{~mm}^{2}$ (b) displays heterogeneous "clonal" proliferation, as assessed by means of $\mathrm{Ki}-67$, with up to $40 \%$ proliferation index in hot spots (c)
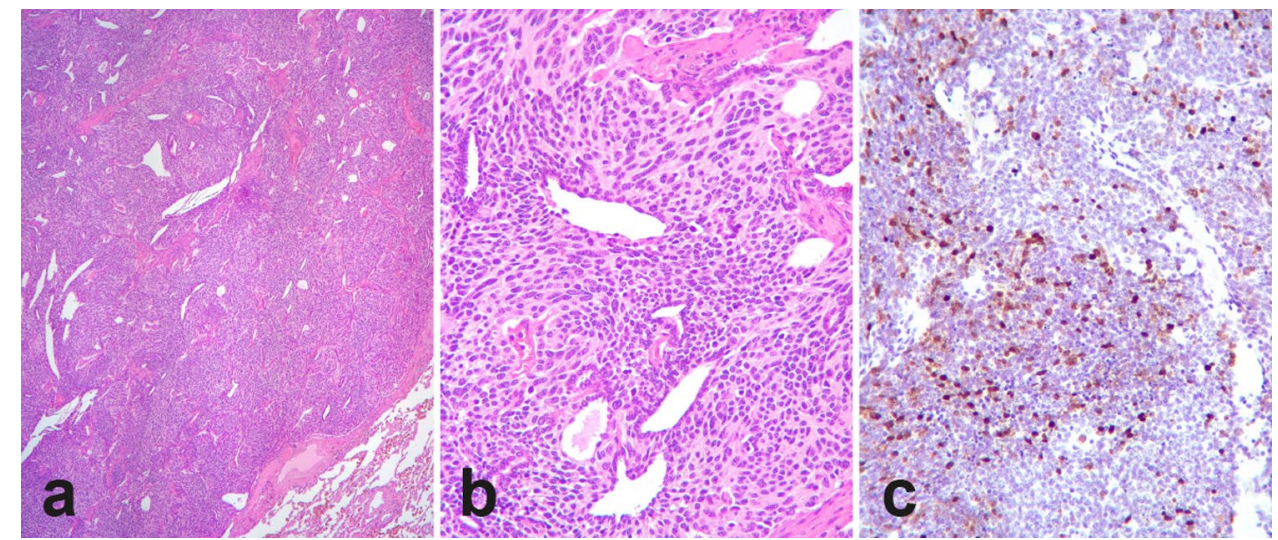


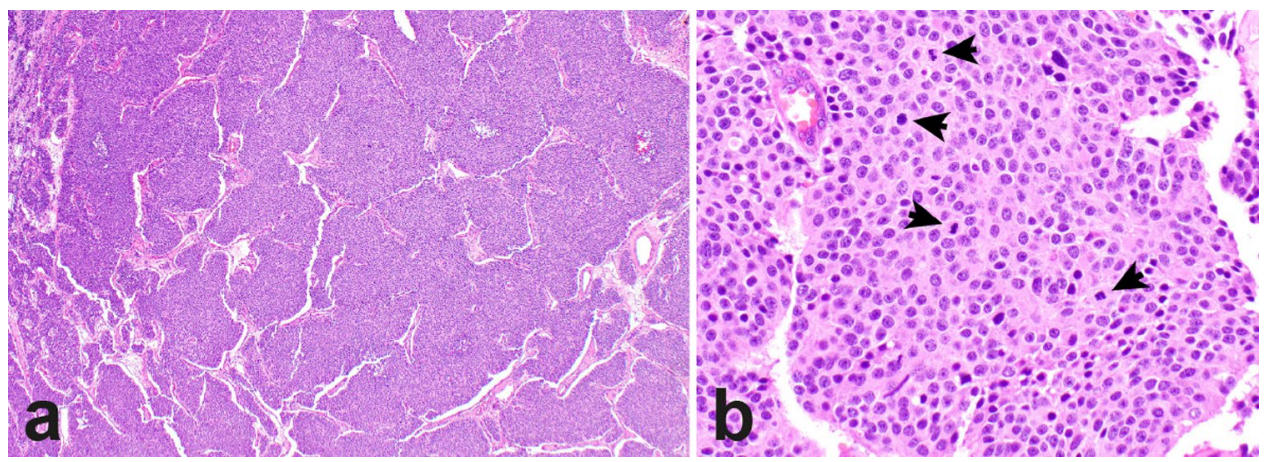

Fig. 2 Thymic neuroendocrine tumors with morphologic features of an atypical carcinoid tumor but with increased mitotic activity. The tumor shows a nested growth pattern and lacks large areas of necrosis (a). High magnification reveals bland appearing round to oval

\section{Molecular Sub-classification of Thoracic Neuroendocrine Neoplasms}

In the last years, a more accurate description of genomic, epigenetic, and gene expression profiles in thoracic neuroendocrine tumors, with special reference to those in the lung, has been achieved. Overall, the available data not only provided prevalence rates of molecular alterations in distinct histological subtypes of neuroendocrine tumors of lung and thymus, but also supported the existence of intermediate molecular classes of thoracic neuroendocrine tumors that parallel the pathological observation of lesions that do cells with a fair amount of cytoplasm and nuclei with inconspicuous nucleoli, lacking prominent nucleoli. Mitotic activity is increased (17 mitoses per $2 \mathrm{~mm}^{2}$, arrows) (b)

not completely fulfill the mitotic index/necrosis-based classification. A descriptive graph illustrating the spectrum of pulmonary neuroendocrine neoplasms according to diverse developmental pathways and putative natural history of disease is reported in Fig. 3. In this scenario, two subsets of neuroendocrine carcinomas are identified [21]. Primary neuroendocrine carcinomas feature undifferentiated tumor cells characterized by severe gene alterations (e.g., biallelic inactivation of $R B 1$ and TP53) responsible for de novo pathogenetic mechanisms. They are characterized by a very short preclinical phase and high clinical aggressiveness with extensive disease at presentation. These tumors account for
Fig. 3 Reappraisal of the lung neuroendocrine neoplasia spectrum according to diverse developmental pathways and putative natural history of disease. Green and yellow triangles with opposite slope indicate tumor aggressiveness and putative duration of preclinical phase, respectively. LCNEC large-cell neuroendocrine carcinoma, SCLC small-cell lung carcinoma, NET neuroendocrine tumor, P-HGNEN primary high grade neuroendocrine neoplasm, S-HGNEN secondary high-grade neuroendocrine neoplasm, I-NET indolent neuroendocrine tumor, TC typical carcinoid, AC atypical carcinoid, NSCLC non-small cell lung cancer

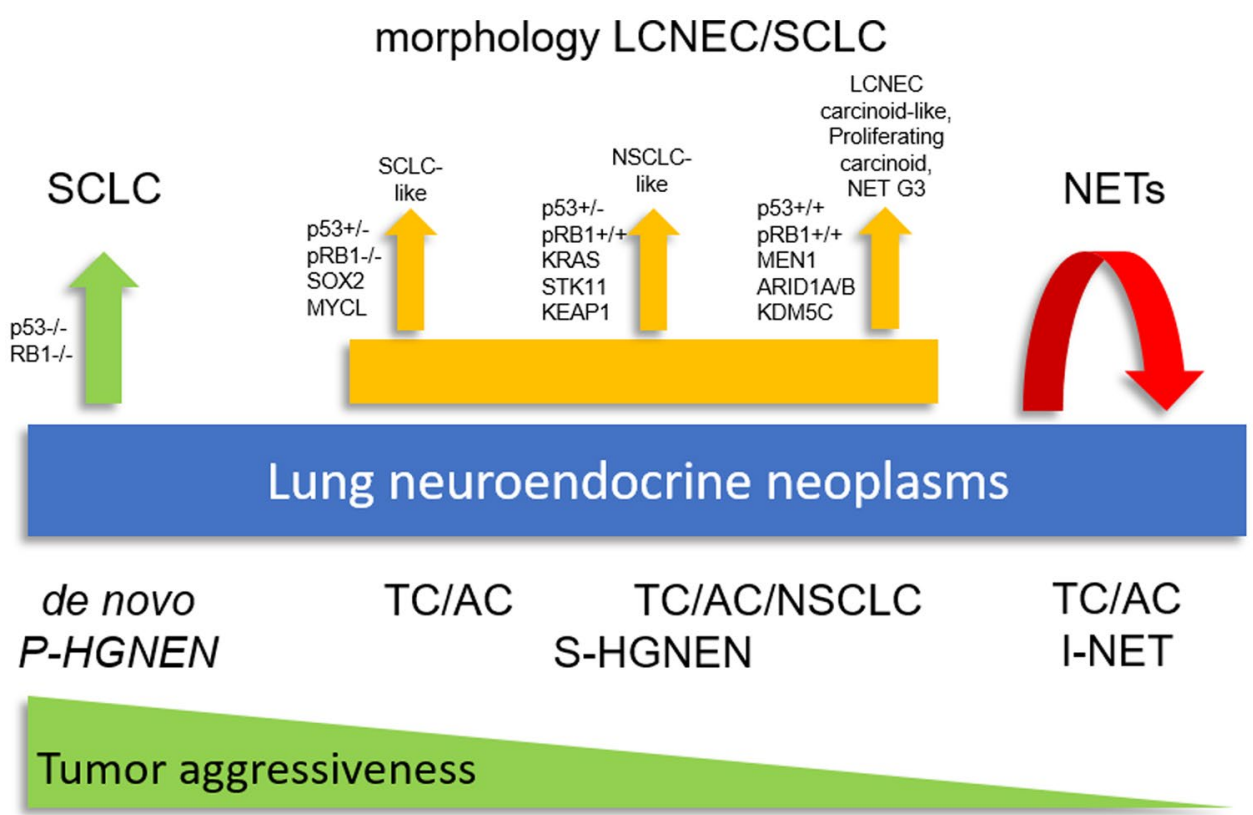

Preclinical phase duration 
the vast majority (approximately 70\%) of neuroendocrine carcinomas.

In terms of morphologic and molecular characteristics, secondary neuroendocrine carcinomas, which are linked to tumor progression from pre-existing lesions, often show greater heterogeneity than primary ones. Similar tumors occur in both the lung and the thymus [20]. In this setting, secondary neuroendocrine carcinomas can develop through the acquisition of diverse genetic alterations either from neuroendocrine tumors (carcinoids) at high risk of progression or from non-small cell lung carcinomas. Duration of the preclinical phase is inversely related to tumor aggressiveness. Conversely, carcinoid-like large-cell neuroendocrine carcinoma would merge within the recently proposed category of neuroendocrine tumors with elevated proliferation rates in the lung (similar to gastro-entero-pancreatic neuroendocrine tumors with high grade proliferation; Grade 3 NET) [22] and might derive from neuroendocrine tumors (carcinoids) that have an increased risk of progression. These tumors would be characterized by a variably long preclinical phase (especially carcinoid-like large cell neuroendocrine carcinomas) and a clinical aggressiveness that is somewhat intermediate between de novo neuroendocrine carcinomas and indolent neuroendocrine tumors. These tumors would show lower propensity to metastasis formation at presentation. Finally, there are also indolent neuroendocrine tumors that are destined to remain unchanged over time and feature carcinoids with the longest preclinical phase and negligible clinical aggressiveness.

\section{Genomic Profiling of Pulmonary Neuroendocrine Tumors (Carcinoid Tumors)}

The genomic profiling of pulmonary neuroendocrine tumors (carcinoids) has been recently investigated by means of highthroughput next-generation techniques [23]. Despite some heterogeneity of results in terms of prevalence of mutations in individual genes, molecular studies of pulmonary neuroendocrine tumors overall indicate that:

(i) Carcinoids are characterized by a low mutational burden, with a slight increase from typical to atypical carcinoids, but invariably lower than large-cell and small-cell neuroendocrine carcinomas;

(ii) G:C $>\mathrm{A}: \mathrm{T}$ transitions, which are characteristic of smoking exposure, are less frequent in carcinoids as compared with neuroendocrine carcinomas;

(iii) Chromatin remodeling and histone modificationrelated genes are mostly altered, whereas mutations in genes frequently altered in neuroendocrine carcinomas (such as $R B 1$ and TP53) are very rare but not absent.
Globally, mutations in chromatin remodeling genes have been detected with variable frequencies, in up to more than $40 \%$ of pulmonary neuroendocrine tumors in some studies [24-27]. Lower rates of mutations in chromatin remodeling genes have been detected in other studies [28, 29], probably as the result of differences in variant calling algorithms as well as different filtering parameters, thus emphasizing the need for standardization of bioinformatics and uniformity of quality control [30]. Genes involved in chromatin remodeling are divided in two main groups: those encoding for components of the covalent histone-modifying complexes (acetylation, methylation, phosphorylation, and ubiquitination) and those encoding for complexes of adenosine triphosphate-dependent chromatin remodeling (such as the SWI/SNF). Overall, MEN1 is the most frequently somatically mutated gene in neuroendocrine tumors (identified in $11-22 \%$ of carcinoids) [31, 32], which is usually associated to loss of heterozygosity [23, 24]. MEN1 is a histone modifier acting as a scaffold protein into a ternary complex composed of MEN1-MLL-PC4 and SFRS1 interacting protein 1 gene $(P S I P I)$. Interestingly, $P S I P I$ has also been found to be mutated in a subset of neuroendocrine tumors (5\%) lacking $M E N 1$ gene alterations [24]. Interestingly, $M E N 1$ gene mutations and reduced gene expression have been associated with poor prognosis in pulmonary neuroendocrine tumors, thus representing a prognostic molecular biomarker in these neoplasms [25, 33]. Other genes belonging to the chromatin remodeling pathway include those of the KMT2 (MLL) family of covalent histone modifiers whose mutation rate is up to $14 \%$ [25]. Genes of the SWI/SNF complex were also found to be mutated in more than $20 \%$ of neuroendocrine tumors of the lung, including genes of the ARID1 family, BCL11A, SMARCA1, SMARCA2, SMARCA4, SMARCB1, and SMARCC2 [24, 25].

Other pathways are by far less commonly altered in pulmonary neuroendocrine tumors. Recurrent mutations in the kinase domain of PIK3CA (exon 9 and 20) have been described in $13 \%$ of typical carcinoids and $39 \%$ of atypical carcinoids by means of Sanger sequencing [34]. However, lower prevalence rates of mutations in gene belonging to the $\mathrm{PI} 3 \mathrm{~K} / \mathrm{AKT} / \mathrm{mTOR}$ pathway have been detected in more recent next-generation sequencing studies, in contrast to neuroendocrine carcinomas [25].

Rare pulmonary neuroendocrine tumors have been described to show a hypermutated profile associated with $P O L Q$ mutations, a gene involved in DNA double-strand break repair and homologous recombination mechanisms [25, 27]. Moreover, a panel of chromosomal rearrangements, including the TRIB2-PRKCE fusion that involves a tyrosine kinase gene, has been recently described and associated with disease recurrence in a cohort of 25 pulmonary carcinoids [29]. 
Despite the relative abundance of studies, the comparative molecular characterization of typical vs atypical carcinoids is still incomplete. Overall, typical carcinoids have the lowest mutational burden and the lowest mutational rate for each altered gene [35]. The most frequently mutated genes are EIFIAX, ARIDIA, LRPIB, and $N F 1$. By contrast, atypical carcinoids show a higher rate of mutations for each altered gene and a similar but not identical set of mutations. In fact, although mutation rates of EIFIAX and ARIDIA are in line with those of typical carcinoids, a higher prevalence of $M E N 1$ mutations is observed in atypical carcinoids as compared with typical carcinoids, reaching $25 \%$. Other genes which are significantly mutated in atypical as compared to typical carcinoids include SMARCA4, ATP1A2, and SPHKAP, all with a mutation frequency exceeding $10 \%$ [35]. Interestingly, mutations in genes implicated in chromatin remodeling and histone modification are exclusive (such as $E I F 1 A X)$ or generally more frequent in carcinoids as compared with large-cell and small-cell neuroendocrine carcinomas. It is worth to notice that mutations of other genes involved in chromatin remodeling such as DAXX or $A T R X$ are not detected in pulmonary carcinoids, in contrast to other neuroendocrine tumors of foregut origin (i.e., those in the pancreas) [36]. However, in an immunohistochemical study of over 100 cases, it has been shown that loss of ATRX protein is present in $20 \%$ of pulmonary carcinoids, with a significant association with atypical carcinoids and shorter disease-specific survival [37].

Molecular alterations that are typical of non-small cell lung cancer, including those that are targets for biologic therapy, are infrequent in pulmonary neuroendocrine tumors. ALK or NTRK fusions are very rarely detected in pulmonary carcinoids, with only single cases reported [38, 39], including cases with well-differentiated morphology but high proliferative rate [40].

Finally, several molecular studies, in parallel to morphology as discussed above, suggest that a subgroup of carcinoid tumors (mainly atypical carcinoid tumors) and large-cell neuroendocrine carcinomas display a heterogeneity with some overlap between histological types, and that a molecular classification may allow a better prognostic and predictive stratification. For instance, a recent study aimed at the integrative analysis of genome, transcriptome, and methylome data showed that integrated molecular profiles depict specific survival outcomes in patients with carcinoid tumors of atypical morphology, segregating patients with good typical carcinoid-like survival and patients with worse clinical outcome similar to large-cell neuroendocrine carcinomas [27]. In this study, a specific subgroup of neuroendocrine tumors, termed supracarcinoids, was identified with morphological features of carcinoid tumors but with molecular characteristics similar to large-cell neuroendocrine carcinomas. These tumors were characterized by MKI67 gene expression levels higher than seen in other carcinoid molecular subtypes, high estimated levels of neutrophil infiltration, altered pathways related to chemotaxis and degranulation of neutrophil, high levels of expression of immune checkpoint receptors and ligands (such as PDL1 and CTLA4), and upregulation of other immunosuppressive genes (including HLA-G and interferon gamma). Moreover, a few small studies were specifically aimed at the molecular characterization of highly proliferative lung carcinoids. In a series of cases at advanced stage of disease, no alterations in $R B 1$ or TP53 were detected, whereas mutations on chromatin-modifier genes (MENI, ARIDIA, ARIDIB, and KDM5C) were present in more than $50 \%$ of cases [41]. In another study [42], highly proliferative pulmonary neuroendocrine tumors displayed molecular alterations in tumor suppressor genes belonging to pathways commonly altered in both carcinoids and neuroendocrine carcinomas of the lung, including chromatin remodeling, DNA repair, and cell cycle. Moreover, based on data in cases with spatial and/or temporal heterogeneity, this study proposes an evolutionary model from clones of lower aggressivity through the accumulation of "neuroendocrine carcinoma-like" genetic alterations, such as TP53/RBI alterations.

\section{Gene Expression Profiling of Pulmonary Neuroendocrine Tumors (Carcinoid Tumors)}

Gene expression profiling in pulmonary carcinoids has been assessed mainly in two different settings. The first was tailored to identify gene signatures specific to carcinoid histotypes. A study by Toffalorio et al. [43] identified 273 genes to be upregulated in the atypical vs typical histotype, and among those GC (encoding for a vitamin D-binding protein) and CEACAM1 (encoding for a carcinoembryonic antigen family member) were validated by quantitative PCR and immunohistochemistry and proposed as potent diagnostic markers.

In another setting, gene expression profiling analysis was applied to identify signatures associated with specific biological and clinical behavior. In pulmonary neuroendocrine tumors with poor prognosis, a set of genes was found to be upregulated, including the proto-oncogene $R E T$ and other genes involved in cell cycle control, such as $A S P M, B I R C 5, B U B 1, C E P 55, F A N C A$, and others, whereas OTP, PCK1, ASB4, FOLRI1, CD44, and others were downregulated [44]. Interestingly, BIRC5, BUB1, CD44, IL2ORA, KLK12, and OTP were independent predictors of patient outcome. Larger and independent series confirmed the negative prognostic value of the loss of $O T P$ and $C D 44$, proposing them as relevant clinical biomarkers of aggressiveness [45-47]. 
In line with genomic data, recent transcriptional studies supported the existence of a grey zone between atypical carcinoid tumors and large-cell neuroendocrine carcinomas. In one study, atypical carcinoid tumors and large-cell neuroendocrine carcinomas have been clustered into three groups. Two groups were enriched for atypical carcinoid tumors or large-cell neuroendocrine carcinomas, respectively, and the genomic findings and outcome of the patients were as would be expected for the respective histotype. A third group was composed of mixed histologies, intermediate molecular features, and a survival similar to atypical carcinoid-type cluster [48]. In another study, neuroendocrine tumors or large-cell neuroendocrine carcinomas were analyzed by RNA sequencing and data matched with clinical and pathological features [49]. The study included four samples classified as borderline neuroendocrine tumor because of the presence of welldifferentiated neuroendocrine morphology and increased Ki-67 or mitotic rates. Clustering analysis revealed two distinct molecular groups characterized by low or high proliferation, the former including seven carcinoids and three borderline tumors, and the latter including seven largecell neuroendocrine carcinomas and one borderline tumor.

\section{Epigenetic Molecular Mechanisms in Pulmonary Neuroendocrine Tumors (Carcinoid Tumors)}

In line with the overall low mutation rates and the few recurrently mutated genes, neuroendocrine tumors are characterized by chromatin remodeling and epigenetic changes, which seem to represent the most relevant molecular mechanisms underlying the pathogenesis of these tumors. Although most of the available data have been obtained in pancreatic and intestinal neuroendocrine tumors, DNA methylation, histone modification, and miRNA expression have also been described in pulmonary carcinoids.

In detail, promoter hypermethylation of $R A S$-association domain family 1 ( $R A S S F 1$ ) gene has been reported to be a frequent event in typical and atypical carcinoids, with a significant association between higher degrees of promoter methylation and higher tumor grade [50]. Intriguingly, in the same study, a non-linear correlation between mRNA and protein levels was observed, suggesting that posttranscriptional events may regulate the function of RASSF 1 gene [50].

Another gene showing promoter hypermethylation in pulmonary carcinoids is $C D K N 2 B$, coding for a cyclindependent kinase inhibitor p15Ink $4 \mathrm{~b}$ which is functionally similar to the tumor-suppressor gene $C D K N 2 A$ (encoding for the p16INK4a protein), but less well characterized in its tumorigenic potential. It has been shown that the expression of the p15INK4b gene product (p15) was significantly lower in lung neuroendocrine neoplasms, especially in neuroendocrine tumors, as well as in the adjacent normal lung, compared with non-neoplastic control lungs. This finding was at least partially associated with aberrant methylation at the 5 '-region of the gene [51]. However, the real role of $C D K N 2 B$ gene promoter hypermethylation in the pathogenesis of pulmonary carcinoids is still a matter of debate [52].

Methylation levels of the MCAM gene (a protean modulator of a number of cellular functions, including cell motility and matrix invasion) were demonstrated to be significantly higher in lung carcinoids than in other neuroendocrine neoplasms, supporting its role as a sitespecific molecular biomarker [53]. More recently, the $K E A P 1$ gene silencing by promoter methylation was reported in about $50 \%$ of typical and atypical lung carcinoids, which correlated with reduced protein expression $[54,55]$.

The importance of the regulation of DNA methylation in the pathogenesis of pulmonary neuroendocrine tumors is also reflected by the finding of the overexpression in these tumors of enzymes active in DNA methylation. For example, nuclear overexpression of the protein arginine methyltransferase-5 (PRMT5), which is a chromatinmodifying enzyme, was reported to be more frequent in pulmonary carcinoids than in neuroendocrine carcinomas, suggesting different epigenetic regulatory mechanisms controlling oncogenesis in carcinoids as compared with high-grade pulmonary neuroendocrine neoplasms [56]. Conversely, tumor grade has been shown to be inversely correlated with expression levels of the histone methyltransferase enhancer of zeste homolog 2 (EZH2), being identified in neuroendocrine carcinomas of the lung, but lacking in pulmonary carcinoids [57].

A few systematic studies are available regarding histone modifications in pulmonary carcinoids. The expression of histone $\mathrm{H} 4$ acetylation at lysine 16 (H4KA16) and trimethylation at lysine 20 (H4KM20) was analyzed in a series of 32 pulmonary neuroendocrine neoplasms, showing a progressive loss of H4KM20 and H4KA16 along the spectrum of neuroendocrine neoplasms. Namely, typical carcinoids showed no alterations of histone $\mathrm{H} 4$, whereas early changes were observed in atypical carcinoids, and widespread loss of H4KM20 and H4KA16 was present in neuroendocrine carcinomas [58].

Concerning non-coding RNAs, the analysis of miRNAs expression profile in pulmonary neuroendocrine tumors demonstrated peculiar features which are different from neuroendocrine carcinomas of the lung and more similar to digestive neuroendocrine tumors [59-62]. Interestingly, typical and atypical carcinoids have been reported to differentially express specific miRNA subsets and, in addition, distinct miRNA expression profiles have been described in metastatic cases $[59,60]$. 
Long non-coding RNA profiling in pulmonary neuroendocrine neoplams has only been explored in a single study. In that study, the expression of HOX transcript antisense RNA (HOTAIR), maternally expressed 3 (MEG3), and prostate cancer antigen 3 (PCA3) has been found to be significantly lower in pulmonary carcinoids as compared with neuroendocrine carcinomas. The functional significance of this observation still needs to be explored [63].

Overall, our current knowledge of epigenetic changes involved in the molecular pathogenesis of pulmonary neuroendocrine tumors not only represents additional and complementary information to better understand tumor development and progression but also provides useful diagnostic tools in the distinction between carcinoids and neuroendocrine carcinomas. In addition, several epigenetic mechanisms are potential therapeutic targets in view of a tailored target therapy.

\section{Molecular Background of Thymic Neuroendocrine Tumors (Carcinoid Tumors)}

Using low-coverage whole-genome sequencing and copy number instability (CNI) scoring, Dinter et al. showed that the average CNI ranges from 5.25 in typical carcinoids to 18.3 in atypical carcinoids and 44.4 in neuroendocrine carcinomas [19]. However, outliers were observed specifically in cases of atypical carcinoids and large-cell neuroendocrine carcinomas. Overall, based on CNI, the authors were able to identify three clusters in which all thymic neuroendocrine neoplasms fell. $\mathrm{CNI}_{\text {low }}(\mathrm{CNI}<9)$, $\mathrm{CNI}_{\text {int }}(\mathrm{CNI} 9-<30)$, and $\mathrm{CNI}_{\text {high }}(\mathrm{CNI} \geq 30)$. $\mathrm{CNI}_{\text {low }}$ and $\mathrm{CNI}_{\text {int }}$ comprised typical and atypical carcinoid tumors and $44 \%$ of large-cell neuroendocrine carcinomas. $\mathrm{CNI}_{\text {high }}$ contained all small-cell carcinomas, 56\% of large-cell neuroendocrine carcinomas, and $10 \%$ of atypical carcinoids. Interestingly, the CNI clusters correlated with survival. However, the CNI clusters could not be predicted by any morphologic feature, mitotic count, or Ki-67 labeling index. Therefore, the authors proposed a "morphomolecular grading system" for thymic neuroendocrine neoplasms to better predict the prognosis of these tumors (Table 1). The authors also showed that at least in a subset of neuroendocrine neoplasms of the thymus, there might be progression from low- to higher-grade histologies and found some additional focal chromosomal gains and losses in metastatic disease.

Interestingly, in contrast to pulmonary carcinoids, $11 \mathrm{q} 13$ deletions were not identified in thymic neuroendocrine tumors [64, 65]. Gross chromosomal imbalances, as detected by means of comparative genomic hybridization (CGH), occur in $31-88 \%$ of cases $[65,66]$. Similar to the study by Dinter et al. [19], an earlier study by Stroebel et al. [66] using CGH has shown an incremental increase of genetic alterations from typical to atypical carcinoid to neuroendocrine carcinomas with mean numbers of aberrations per tumor of 0.8 in typical carcinoids, 1.1 in atypical carcinoids, 4.7 in large cell neuroendocrine carcinomas, and 15.5 in small-cell carcinomas. The most common findings of CGH studies of thymic neuroendocrine tumors are summarized in Table 2. Frequent overlapping genetic alterations were found in both neuroendocrine tumors and neuroendocrine carcinomas [66]. In that study, a cut-off of 2.5 chromosomal imbalances correlated with a higher rate of recurrence and death rate.

Recent studies have suggested that mRNA transcript analysis in blood can identify thymic neuroendocrine tumors
Table 1 Modified proposal for a "morphomolecular grading system" of thymic neuroendocrine tumors ( Modified from Dinter et al. [19])

\begin{tabular}{llllll}
\hline $\begin{array}{l}\text { Thymic } \\
\text { NET } \\
\text { grade }^{\mathrm{a}}\end{array}$ & $\begin{array}{l}\text { Morphology WHO } \\
\text { subtype }\end{array}$ & $\begin{array}{l}\text { Mitotic Index } \\
(\text { mitoses per } \\
\left.2 \mathrm{~mm}^{2}\right)\end{array}$ & Ki-67 (\%) & CNI score & Immunohistochemistry \\
\hline G1 & Carcinoids & $<10$ & $<9$ & $<9$ & $\begin{array}{l}\text { Chromogranin pos } \text { Ch }^{\mathrm{C}} \\
\text { EZH2 neg } \mathrm{d}, \mathrm{e}\end{array}$ \\
G2 & $\begin{array}{l}\text { Carcinoids } \\
\text { Large-cell NEC }\end{array}$ & $10-29$ & $9-47$ & $9-29$ & $\begin{array}{l}\text { Chromogranin pos } \\
\text { EZH2 neg }\end{array}$ \\
G3 & $\begin{array}{l}\text { Large-cell NEC } \\
\text { Small-cell NEC }\end{array}$ & $\geq 30$ & $\geq 48$ & $\geq 30$ & $\begin{array}{l}\text { Chromogranin pos/neg } \\
\text { EZH2 pos }\end{array}$ \\
\hline
\end{tabular}

NEC neuroendocrine carcinoma

${ }^{\text {a }}$ Proposed morphomolecular thymic neuroendocrine tumor grade

${ }^{\mathrm{b}}$ Carcinoid morphology subtypes also include typical and atypical carcinoids as well as NET G3; the latter is similar to grade-discordant gastroenteropancreatic tract neuroendocrine tumors that are characterized by a well-differentiated (carcinoid) morphology and mitotic count like G2 tumors but increased Ki-67 index (>20\%) equivalent to G3 tumors [107]

${ }^{\mathrm{c}}$ Pos, expressed

${ }^{\mathrm{d}} \mathrm{Neg}$, not expressed

${ }^{\mathrm{e}} \mathrm{EZH} 2 \mathrm{neg}$ defined as $<25 \%$ of tumor cell staining 
Table 2 Results of comparative genomic hybridization studies in thymic neuroendocrine tumors (carcinoids) $[19,62]$

\begin{tabular}{cc}
\hline Subtype of thymic neuroendocrine tumor & Molecular alteration \\
\hline Typical carcinoid tumors & Large copy number altera- \\
tions including \\
Gains on chromosomes \\
$1 \mathrm{q}, 5,6 \mathrm{q}, 7 \mathrm{q}, 8 \mathrm{q}, 10$, \\
$11 \mathrm{q}, 12 \mathrm{q}, 13 \mathrm{q}, 18 \mathrm{q}, 20$, \\
$21 \mathrm{q}, 22 \mathrm{q}$ \\
Losses on chromosomes \\
$1,2 \mathrm{p}, 4 \mathrm{p}, 6 \mathrm{q}, 8,10 \mathrm{p}$, \\
$10 \mathrm{q}, 11 \mathrm{p}, 13 \mathrm{q}, 15 \mathrm{q}, 17 \mathrm{p}$, \\
$18 \mathrm{p}, 22 \mathrm{q}$ \\
Deletions in gene loci on \\
chromosomes $1 \mathrm{p}, 3 \mathrm{q}, 8 \mathrm{p}$, \\
$11 \mathrm{q}, 17 \mathrm{p}$ \\
Large copy number altera- \\
tions including \\
Gains on chromosomes \\
$1 \mathrm{q}, 7 \mathrm{p}, 7 \mathrm{q}, 10,12 \mathrm{q}, 20 \mathrm{q}$, \\
$21,22, X \mathrm{p}$ \\
Losses on chromosomes \\
$1 \mathrm{p}, 2 \mathrm{p}, 3 \mathrm{p}, 4 \mathrm{p}, 4 \mathrm{q}, 6 \mathrm{q}$, \\
$10 \mathrm{p}, 11 \mathrm{p}, 13 \mathrm{q}, 17 \mathrm{p}$ \\
Deletions in gene loci on \\
chromosomes $1 \mathrm{p}, 3 \mathrm{p}$, \\
$3 \mathrm{q}, 5 \mathrm{p}, 6 \mathrm{p}, 6 \mathrm{q}, 9 \mathrm{p}, 10 \mathrm{q}$, \\
$13 \mathrm{q}, 17 \mathrm{p}$ \\
Amplifications in gene \\
loci on chromosomes \\
$8 \mathrm{q}, 14 \mathrm{q}$ \\
\hline
\end{tabular}

[5]. Three non-secretory atypical carcinoid tumors (i.e., no production of serotonin or ACTH) with low chromogranin A levels were found to have detectable expression of genes that have been linked to neuroendocrine tumor pathobiology in the circulating blood using the NETest [5, 67]. However, these findings need to be validated in larger cohorts and their clinical utility in identifying progressive tumors, confirming complete tumor resection, and predicting treatment response has to be established.

Mutational burden is low in thymic neuroendocrine tumors with $<1$ chromosomal alteration per tumor which occurs in less than a third of patients [66]. Approximately $25 \%$ of patients with thymic carcinoid tumors harbor a MEN1 germline mutation [68] and 8\% of MEN1 patients develop thymic neuroendocrine tumors [69]. However, loss of heterozygosity of the MEN1 locus on chromosome 11q13 has not been described in thymic carcinoids $[65,70]$. One sporadic thymic carcinoid was reported to harbor a nonsense mutation in MEN1 (Q393X) [71].

Evidence suggests that $P A K 3$ (p21-activated kinase 3) might play a role in the progression of ACTH-producing thymic carcinoids [72]. Complementary DNA profiling of 7 ACTH-producing thymic carcinoids identified 5 adhesionrelated genes to be downregulated and 5 to be upregulated including a remarkable overexpression of $P A K 3$ in all tumors. Its upstream regulator, $R A C l$, was also overexpressed. The authors showed that $P A K 3$ overexpression was associated with enhanced cell migration and invasion. Interestingly, $P A K 3$ expression levels were higher in tumors with progressive disease than tumors without. ACTH-secreting tumors were also found to express elevated beta-catenin and decreased NOTCH2 levels, genes involved in the Wnt signaling pathway. Not surprisingly, the neuropeptide signaling pathway was also upregulated, but it was thought that this might have been a consequence of the tumor.

In thymic neuroendocrine tumors, there are currently no potential prognostic biomarkers or targetable molecular alterations known [73]. Furthermore, circulating tumor DNA has not been studied. Therefore, future studies concerning prognostic biomarkers that might better predict the behavior of an individual tumor and targetable molecular aberrations or neoplastic cell proteins are important for the management and treatment of patients with thymic neuroendocrine tumors.

\section{Germline Variants in Lung and Thymic Neuroendocrine Tumors}

Most pulmonary and thymic neuroendocrine tumors (carcinoid tumors) are associated with sporadic disease; thus, only a small fraction is currently linked to germline susceptibility [74]. The age of the patient at time of diagnosis, personal, and/or family history for inherited endocrine tumor syndromes or tumors that may be seen in association with various neuroendocrine neoplasms, cytomorphological findings, and molecular immunohistochemical biomarkers are all important parameters that might prompt diagnosticians to search for a potential underlying germline disease in neuroendocrine neoplasia [74]. Similar to other anatomic sites, the accurate distinction of paragangliomas (non-epithelial neuroendocrine neoplasms of paraganglia) from their epithelial counterparts is of significance since primary pulmonary and mediastinal paragangliomas are more frequently associated with germline alterations [75] compared with thoracic (pulmonary and thymic) neuroendocrine tumors. For this reason, diagnostic immunohistochemical biomarkers of paraganglia (e.g., tyrosine hydroxylase, dopamine beta-hydroxylase, and GATA3) should be applied to all keratin-negative neuroendocrine neoplasms [75-77].

The true incidence of germline susceptibility is currently difficult to determine since clinical studies focusing on germline variants in pulmonary and thymic neuroendocrine tumors are scant. This is partially due to the lack of appreciation of germline disease in apparently sporadicappearing thoracic neuroendocrine neoplasms given the discovery of germline DNA repair defects in non-syndromic 
thoracic neuroendocrine tumors [78]. Ideally, a wholeexome sequencing of germline DNA from all young patients with thoracic neuroendocrine neoplasm and/or any patient with pulmonary neuroendocrine disease either in the form of pulmonary neuroendocrine cell hyperplasia-to-neoplasia sequence or multifocal pulmonary neuroendocrine disease (e.g., solitary pulmonary neuroendocrine tumor in a background of widespread pulmonary neuroendocrine cell hyperplasia, or pulmonary neuroendocrine microtumorsalso known as carcinoid tumorlets, or multifocal pulmonary neuroendocrine tumors) should be integrated into clinical management guidelines.

Among syndromic manifestations, pathogenic MENI variants that cause MEN1 syndrome account for the most well-defined inherited syndrome that can feature thoracic neuroendocrine tumors [79-81]. Among patients with MEN1 syndrome, thymic neuroendocrine neoplasms, which are considered an important source of morbidity, were reported to occur in $3.7 \%$ of MEN1 patients in a recent metaanalysis $[79,80,82]$, whereas pulmonary neuroendocrine neoplasms have been noted in approximately 2-13\% of MEN1 patients [79, 81, 83-87]. The histopathology of MEN1-related lung disease includes more common multifocal neuroendocrine proliferations such as pulmonary neuroendocrine micro-tumors (carcinoid tumorlets) that can be seen in association with pulmonary neuroendocrine cell hyperplasia [81]. The pulmonary neuroendocrine cell hyperplasia-to-neuroendocrine neoplasia progression sequence in MEN1 syndrome can also be screened using molecular immunohistochemistry. For instance, diffuse loss of nuclear menin (protein encoded by MENI) immunostaining in multifocal pulmonary neuroendocrine (micro)tumors or thymic neuroendocrine tumors should alert diagnosticians to the possibility of MEN1 syndrome even in the absence of a family history [88] (Fig. 4). The diagnosis is further justified by demonstrating $M E N 1$ defect in the germline DNA (e.g., blood).

A small fraction of patients with a negative germline MEN1 testing but with MEN1-like clinical and pathological features present with MEN4 syndrome. Affected patients frequently harbor germline pathogenic $C D K N 1 B$ defects [79, 89]. The true incidence of MEN4 syndrome in the context of well-differentiated thoracic neuroendocrine tumors is currently unknown. However, diffuse loss of nuclear p27 (protein encoded by $C D K N 1 B$ ) expression in the appropriate clinical and morphological setting can help rationalize genetic screening to rule out germline $C D K N 1 B$-related thoracic neuroendocrine neoplasia [88].

The identification of pathogenic germline RAD51AC defects in a thymic neuroendocrine tumor [78], as well as a germline $A P C$ variant harboring breast carcinoma patient with a pulmonary neuroendocrine tumor [90] and a germline $\mathrm{MSH} 2$ variant of unknown significance in another breast carcinoma patient with well-differentiated pulmonary neuroendocrine tumor [90], expands the spectrum of nonsyndromic manifestations of germline disease in welldifferentiated thoracic neuroendocrine neoplasms.

Germline NKX2.1 mutations (encoding TTF1) have been reported in patients and their adult family members with familial pulmonary neuroendocrine cell hyperplasia of infancy [91, 92]. Although the pulmonary involvement often shows significant improvement with age, rare examples of adult patients with familial neuroendocrine cell hyperplasia of infancy showed overlapping imaging findings with diffuse idiopathic pulmonary neuroendocrine cell hyperplasia (DIPNECH) [92]. Interestingly, an adult Japanese patient with Notch3-related cerebral autosomal dominant arteriopathy with subcortical infarcts and leucoencephalopathy developed DIPNECH as well as other non-neuroendocrine neoplasms including prostatic
Fig. 4 MEN1 patient with a thymic neuroendocrine tumor that shows diffuse loss of nuclear menin expression, while the non-tumorous elements (internal control) retain nuclear staining for menin

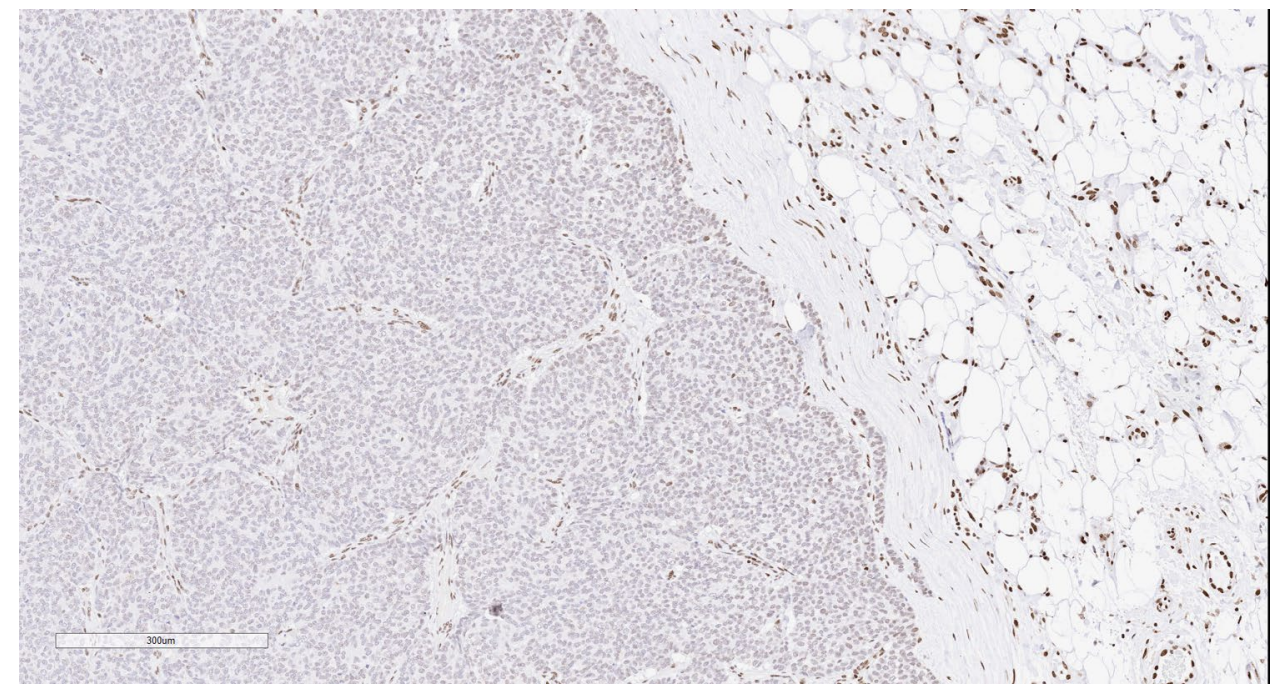


adenocarcinoma, renal cell carcinoma, and adenomatoid tumor (epididymis) [93]. In addition, the occurrence of DIPNECH in the setting of multiple epithelial neoplasms of various organs including papillary thyroid carcinoma, breast carcinoma, and carotid body paraganglioma in a patient with pathogenic $P A L B 2$ is also of great interest [94].

While germline variants in patients with DIPNECH require further studies, the documentation of a common breast carcinoma history and associated germline defects in patients with pulmonary neuroendocrine disease is an interesting pathogenetic association as seen in other neuroendocrine neoplasms [90, 94]. More importantly, these findings suggest that the spectrum of germline disease in thoracic neuroendocrine neoplasia is likely underestimated. Therefore, implementation of routine genetic screening protocols for germline screening is indicated to better understand its incidence and underlying molecular cellular mechanisms.

\section{Implications for Therapy}

Therapeutic strategies and lines of treatment in pulmonary and thymic neuroendocrine tumors in inoperable or progressive cases are poorly defined in current clinical guidelines [95]. In these patients, first-line treatment includes somatostatin analogs alone or in combination with other therapies, or cytotoxic chemotherapy. These same treatments are also the most adopted as second-line therapy, together with mTOR inhibitors and other regimens in a wide range of schemes and sequences that are heterogeneous even within single institutions [96]. Molecular predictive biomarkers in the clinical setting are mostly missing. Specific profiles of expression of somatostatin receptors (mainly loss of expression of somatostatin receptors type 1 and 2 and increased expression of somatostatin receptors type 3 and 4 ) have been associated with the presence of aggressive features and shorter survival in untreated patients [97]. However, although somatostatin analogs proved to be effective treatments in aggressive pulmonary carcinoids [98], somatostatin receptor expression has no role in predicting the response to somatostatin analogs in thoracic well-differentiated neuroendocrine neoplasms. Alkylating agents are the mainstay for chemotherapy, and deficiency of O6-methylguaninemethyltransferase (MGMT) enzyme has been associated with a better response to these agents [99]. However, in lung welldifferentiated neuroendocrine tumors, despite MGMT being shown to be deficient in approximately $50 \%$ of cases [100], no data are available on a predictive role of MGMT status in chemotherapy-treated patients. Although some lines of therapy are based on the biological evidence of the disruption of specific pathways in thoracic neuroendocrine tumors, no clinically relevant molecular biomarker is used to select or predict patient's response to a given treatment. Several molecular alterations in thoracic neuroendocrine tumors interfere with cell-cycle regulation, chromatin remodeling, apoptosis, intracellular cascades, and cell-cell interactions. However, molecular alterations in thoracic neuroendocrine tumors that might be considered as targets for treatment are very scarce, and treatment of pulmonary and thymic carcinoids on a personalized basis is still an unmet goal, despite a list of hypothetical biomarkers [101]. Among those, rovalpituzumab tesirine, which targets the inhibitory Notch ligand Delta-like protein 3 (DLL3), has been shown to be a promising therapeutic agent in pulmonary neuroendocrine carcinomas. Although to a lower extent as compared with small cell lung carcinoma, high DLL3 expression was observed in $37 \%$ of atypical carcinoids and $32.8 \%$ of typical carcinoids [102]. However, the impact of DLL3-targeted therapy in aggressive pulmonary neuroendocrine tumors is unexplored, so far. Chromatin-modifying genes could also be implicated in the treatment of thoracic well-differentiated neuroendocrine neoplasms. As an explicatory model, preliminary literature data showed that ARIDIA alterations increase tumor cell sensitivity to agents targeting the ATR protein, EZH2 or the PI3K pathway [103-105]. Moreover, ARIDIA alterations interfere with mismatch repair pathway and immunoregulatory mechanisms. In fact, ARID1A has been shown to recruit MSH2 to chromatin during DNA replication, and ARID1A inactivation therefore compromises mismatch repair mechanisms. Moreover, in vivo ARIDIAdeficient ovarian cancer models exhibit an increased number of tumor-infiltrating lymphocytes, a higher tumor mutation load, and elevated PD-L1 levels [106]. The supracarcinoid cluster described in the study by Alcala et al. [27] also showed peculiar immune-to-tumor response profiles that suggest a potential role for immunotherapy in aggressive carcinoids of the lung. However, all molecular data described in thoracic neuroendocrine tumors so far lack a direct impact in terms of therapy and still deserve both functional and clinical validation as biomarkers to be integrated to pathological characterization.

Funding Open Access funding provided by Università degli Studi di Torino within the CRUI-CARE Agreement.

\section{Declarations}

Conflict of Interest The authors declare that they have no conflict of interest.

Open Access This article is licensed under a Creative Commons Attribution 4.0 International License, which permits use, sharing, adaptation, distribution and reproduction in any medium or format, as long as you give appropriate credit to the original author(s) and the source, provide a link to the Creative Commons licence, and indicate if changes were made. The images or other third party material in this article are included in the article's Creative Commons licence, unless indicated otherwise in a credit line to the material. If material is not included in the article's Creative Commons licence and your intended 
use is not permitted by statutory regulation or exceeds the permitted use, you will need to obtain permission directly from the copyright holder. To view a copy of this licence, visit http://creativecommons. org/licenses/by/4.0/.

\section{References}

1. Yao JC, Hassan M, Phan A, Dagohoy C, Leary C, Mares JE, Abdalla EK, Fleming JB, Vauthey JN, Rashid A, Evans DB (2008) One hundred years after "carcinoid": epidemiology of and prognostic factors for neuroendocrine tumors in 35,825 cases in the United States. J Clin Oncol 26:3063-72. doi: https://doi. org/10.1200/JCO.2007.15.4377

2. Kneuertz PJ, Kamel MK, Stiles BM, Lee BE, Rahouma M, Harrison SW, Altorki NK, Port JL (2018) Incidence and Prognostic Significance of Carcinoid Lymph Node Metastases. Ann Thorac Surg 106:981-988. doi: https://doi.org/10.1016/j. athoracsur.2018.05.044

3. Abdel-Rahman O (2018) Modified staging system for pulmonary carcinoids on the basis of lung cancer TNM system. Clin Transl Oncol 20:670-677. doi: https://doi.org/10.1007/s12094-017-1759-2

4. Dermawan JK, Farver CF (2019) The Prognostic Significance of the 8th Edition TNM Staging of Pulmonary Carcinoid Tumors: A Single Institution Study With Long-term Follow-up. Am J Surg Pathol 43:1291-1296. doi: https://doi.org/10.1097/PAS.0000000000001268

5. Modlin IM, Kidd M, Filosso PL, Roffinella M, Lewczuk A, Cwikla J, Bodei L, Kolasinska-Cwikla A, Chung KM, Tesselaar ME, Drozdov IA (2017) Molecular strategies in the management of bronchopulmonary and thymic neuroendocrine neoplasms. J Thorac Dis 9:S1458-S1473. doi: https://doi.org/10.21037/jtd.2017.03.82

6. Travis W, Brambilla E, Burke A, Marx A, Nicholson A. WHO Classification of Tumours of the Lung, Pleura, Thymus and Heart. IARC Press, Lyon, 2015

7. Robelin P, Hadoux J, Forestier J, Planchard D, Hervieu V, Berdelou A, Scoazec JY, Valette PJ, Leboulleux S, Ducreux M, Lombard-Bohas C, Baudin E, Walter T (2019) Characterization, Prognosis, and Treatment of Patients With Metastatic Lung Carcinoid Tumors. J Thorac Oncol 14:993-1002. doi: https:// doi.org/10.1016/j.jtho.2019.02.002

8. Moran CA, Lindholm KE, Brunnström H, Langman G, Jang SJ, Spagnolo D, Chai SM, Laycock A, Falconieri G, Pizzolitto S, de Pellegrin A, Medeiros F, Edmunds L, Catarino A, Cunha F, Ro J, Pina-Oviedo S, Torrealba J, Coppola D, Petersson F, Oon ML, Elmberger G, Y Cajal SR, Valero IS, Dalurzo L, Soares F, Campos AH, Vranic S, Skenderi F, Correa AM, Sepesi B, Rice D, Mehran R, Walsh G (2020) Typical and atypical carcinoid tumors of the lung: a clinicopathological correlation of 783 cases with emphasis on histological features. Hum Pathol 98:98-109. doi: https://doi.org/10.1016/j.humpath.2020.02.005

9. Rindi G, Klersy C, Inzani F, Fellegara G, Ampollini L, Ardizzoni A, Campanini N, Carbognani P, De Pas TM, Galetta D, Granone PL, Righi L, Rusca M, Spaggiari L, Tiseo M, Viale G, Volante M, Papotti M, Pelosi G (2013) Grading the neuroendocrine tumors of the lung: an evidence-based proposal. Endocr Relat Cancer 21:1-16. doi: https://doi.org/10.1530/ERC-13-0246

10. Marchevsky AM, Hendifar A, Walts AE (2018) The use of Ki-67 labeling index to grade pulmonary well-differentiated neuroendocrine neoplasms: current best evidence. Mod Pathol 31:1523-1531. doi: https://doi.org/10.1038/s41379-018-0076-9

11. Dermawan JKT, Farver CF (2020) The Role of Histologic Grading and Ki-67 Index in Predicting Outcomes in Pulmonary Carcinoid Tumors. Am J Surg Pathol 44:224-231. doi: https:// doi.org/10.1097/PAS.0000000000001358.
12. Marchiò C, Gatti G, Massa F, Bertero L, Filosso P, Pelosi G, Cassoni P, Volante M, Papotti M (2017) Distinctive pathological and clinical features of lung carcinoids with high proliferation index. Virchows Arch 471:713-720. doi: https://doi.org/10.1007/ s00428-017-2177-0

13. Kasajima A, Konukiewitz B, Oka N, Suzuki H, Sakurada A, Okada Y, Kameya T, Ishikawa Y, Sasano H, Weichert W, Klöppel G (2019) Clinicopathological Profiling of Lung Carcinoids with a Ki67 Index > 20. Neuroendocrinology 108:109-120. doi: https:// doi.org/10.1159/000495806

14. Rubino M, Scoazec JY, Pisa E, Faron M, Spaggiari L, Hadoux J, Spada F, Planchard D, Cella CA, Leboulleux S, De Marinis F, Ducreux M, Lamartina L, Baudin E, Fazio N (2020) Lung carcinoids with high proliferative activity: Further support for the identification of a new tumor category in the classification of lung neuroendocrine neoplasms. Lung Cancer 148:149-158. doi: https://doi.org/10.1016/j.lungcan.2020.08.001

15. Hermans BCM, Derks JL, Moonen L, Habraken CHJ, der Thüsen JV, Hillen LM, Speel EJM, Dingemans AC (2020) Pulmonary neuroendocrine neoplasms with well differentiated morphology and high proliferative activity: illustrated by a case series and review of the literature. Lung Cancer 150:152-158. doi: https:// doi.org/10.1016/j.lungcan.2020.10.015

16. Quinn AM, Chaturvedi A, Nonaka D (2017) High-grade Neuroendocrine Carcinoma of the Lung With Carcinoid Morphology: A Study of 12 Cases. Am J Surg Pathol 41:263270. doi: https://doi.org/10.1097/PAS.0000000000000767

17. Ie $S$, Boyd M (2015) New cancer or carcinoid progression to small cell lung cancer? J Bronchology Interv Pulmonol 22:186-8. doi: https://doi.org/10.1097/LBR.0000000000000147

18. Pelosi G, Bianchi F, Dama E, Simbolo M, Mafficini A, Sonzogni A, Pilotto S, Harari S, Papotti M, Volante M, Fontanini G, Mastracci L, Albini A, Bria E, Calabrese F, Scarpa A (2018) Most high-grade neuroendocrine tumours of the lung are likely to secondarily develop from pre-existing carcinoids: innovative findings skipping the current pathogenesis paradigm. Virchows Arch 472:567-577. doi: https://doi.org/10.1007/ s00428-018-2307-3

19. Dinter H, Bohnenberger H, Beck J, Bornemann-Kolatzki K, Schütz E, Küffer S, Klein L, Franks TJ, Roden A, Emmert A, Hinterthaner M, Marino M, Brcic L, Popper H, Weis CA, Pelosi G, Marx A, Ströbel P (2019) Molecular Classification of Neuroendocrine Tumors of the Thymus. J Thorac Oncol 14:14721483. doi: https://doi.org/10.1016/j.jtho.2019.04.015

20. Fabbri A, Cossa M, Sonzogni A, Bidoli P, Canova S, Cortinovis D, Abbate MI, Calabrese F, Nannini N, Lunardi F, Rossi G, La Rosa S, Capella C, Tamborini E, Perrone F, Busico A, Capone I, Valeri B, Pastorino U, Albini A, Pelosi G (2017) Thymus neuroendocrine tumors with CTNNB1 gene mutations, disarrayed B-catenin expression, and dual intra-tumor Ki-67 labeling index compartmentalization challenge the concept of secondary high-grade neuroendocrine tumor: a paradigm shift. Virchows Arch 471:31-47. doi: https://doi.org/10.1007/ s00428-017-2130-2

21. Pelosi G, Bianchi F, Hofman P, Pattini L, Ströbel P, Calabrese F, Naheed S, Holden C, Cave J, Bohnenberger H, Dinter H, Harari S, Albini A, Sonzogni A, Papotti M, Volante M, Ottensmeier CH (2019) Recent advances in the molecular landscape of lung neuroendocrine tumors. Expert Rev Mol Diagn 19:281-297. doi: https://doi.org/10.1080/ 14737159.2019.1595593

22. Kasajima A, Klöppel G (2020) Neuroendocrine neoplasms of lung, pancreas and gut: a morphology-based comparison. Endocr Relat Cancer 27:R417-R432. doi: https://doi.org/10.1530/ ERC-20-0122 
23. Derks JL, Leblay N, Lantuejoul S, Dingemans AC, Speel EM, Fernandez-Cuesta L (2018) New Insights into the Molecular Characteristics of Pulmonary Carcinoids and Large Cell Neuroendocrine Carcinomas, and the Impact on Their Clinical Management. J Thorac Oncol 13:752-766. doi: https://doi. org/10.1016/j.jtho.2018.02.002

24. Fernandez-Cuesta L, Peifer M, Lu X, Sun R, Ozretić L, Seidal D, Zander T, Leenders F, George J, Müller C, Dahmen I, Pinther B, Bosco G, Konrad K, Altmüller J, Nürnberg P, Achter V, Lang U, Schneider PM, Bogus M, Soltermann A, Brustugun OT, Helland Å, Solberg S, Lund-Iversen M, Ansén S, Stoelben E, Wright GM, Russell P, Wainer Z, Solomon B, Field JK, Hyde R, Davies MP, Heukamp LC, Petersen I, Perner S, Lovly C, Cappuzzo F, Travis WD, Wolf J, Vingron M, Brambilla E, Haas SA, Buettner R, Thomas RK (2014) Frequent mutations in chromatin-remodelling genes in pulmonary carcinoids. Nat Commun 5:3518. doi: https:// doi.org/10.1038/ncomms4518

25. Simbolo M, Mafficini A, Sikora KO, Fassan M, Barbi S, Corbo V, Mastracci L, Rusev B, Grillo F, Vicentini C, Ferrara R, Pilotto S, Davini F, Pelosi G, Lawlor RT, Chilosi M, Tortora G, Bria E, Fontanini G, Volante M, Scarpa A (2017) Lung neuroendocrine tumours: deep sequencing of the four World Health Organization histotypes reveals chromatin-remodelling genes as major players and a prognostic role for TERT, RB1, MEN1 and KMT2D. J Pathol 241:488-500. doi: https://doi.org/10.1002/path.4853

26. Laddha SV, da Silva EM, Robzyk K, Untch BR, Ke H, Rekhtman N, Poirier JT, Travis WD, Tang LH, Chan CS (2019) Integrative Genomic Characterization Identifies Molecular Subtypes of Lung Carcinoids. Cancer Res 79:4339-4347. doi: https://doi. org/10.1158/0008-5472.CAN-19-0214

27. Alcala N, Leblay N, Gabriel AAG, Mangiante L, Hervas D, Giffon T, Sertier AS, Ferrari A, Derks J, Ghantous A, Delhomme TM, Chabrier A, Cuenin C, Abedi-Ardekani B, Boland A, Olaso R, Meyer V, Altmuller J, Le Calvez-Kelm F, Durand G, Voegele C, Boyault S, Moonen L, Lemaitre N, Lorimier P, Toffart AC, Soltermann A, Clement JH, Saenger J, Field JK, Brevet M, BlancFournier C, Galateau-Salle F, Le Stang N, Russell PA, Wright G, Sozzi G, Pastorino U, Lacomme S, Vignaud JM, Hofman V, Hofman P, Brustugun OT, Lund-Iversen M, Thomas de Montpreville V, Muscarella LA, Graziano P, Popper H, Stojsic J, Deleuze JF, Herceg Z, Viari A, Nuernberg P, Pelosi G, Dingemans AMC, Milione M, Roz L, Brcic L, Volante M, Papotti MG, Caux C, Sandoval J, Hernandez-Vargas H, Brambilla E, Speel EJM, Girard N, Lantuejoul S, McKay JD, Foll M, Fernandez-Cuesta L (2019) Integrative and comparative genomic analyses identify clinically relevant pulmonary carcinoid groups and unveil the supra-carcinoids. Nat Commun 10:3407. doi: https://doi. org/10.1038/s41467-019-11276-9

28. Asiedu MK, Thomas CF Jr, Dong J, Schulte SC, Khadka P, Sun Z, Kosari F, Jen J, Molina J, Vasmatzis G, Kuang R, Aubry MC, Yang P, Wigle DA (2018) Pathways Impacted by Genomic Alterations in Pulmonary Carcinoid Tumors. Clin Cancer Res 24:1691-1704. doi: https://doi.org/10.1158/1078-0432.CCR-17-0252

29. Miyanaga A, Masuda M, Motoi N, Tsuta K, Nakamura Y, Nishijima N, Watanabe SI, Asamura H, Tsuchida A, Seike M, Gemma A, Yamada T (2020) Whole-exome and RNA sequencing of pulmonary carcinoid reveals chromosomal rearrangements associated with recurrence. Lung Cancer 145:85-94. doi: https:// doi.org/10.1016/j.lungcan.2020.03.027

30. Gabriel AAG, Mathian E, Mangiante L, Voegele C, Cahais V, Ghantous A, McKay JD, Alcala N, Fernandez-Cuesta L, Foll M (2020) A molecular map of lung neuroendocrine neoplasms. Gigascience 9:giaa112. doi: https://doi.org/10.1093/gigascience/giaa112

31. Görtz B, Roth J, Krähenmann A, de Krijger RR, Muletta-Feurer S, Rütimann K, Saremaslani P, Speel EJ, Heitz PU, Komminoth $P$ (1999) Mutations and allelic deletions of the MEN1 gene are associated with a subset of sporadic endocrine pancreatic and neuroendocrine tumors and not restricted to foregut neoplasms. Am J Pathol 154:429-36. doi: https://doi.org/10.1016/ S0002-9440(10)65289-3

32. Veschi S, Lattanzio R, Aceto GM, Curia MC, Magnasco S, Angelucci D, Cama A, Piantelli M, Battista P (2012) Alterations of MEN1 and E-cadherin/ $\beta$-catenin complex in sporadic pulmonary carcinoids. Int J Oncol 41:1221-8. doi: https://doi. org/10.3892/ijo.2012.1563

33. Swarts DR, Scarpa A, Corbo V, Van Criekinge W, van Engeland M, Gatti G, Henfling ME, Papotti M, Perren A, Ramaekers FC, Speel EJ, Volante M (2014) MEN1 gene mutation and reduced expression are associated with poor prognosis in pulmonary carcinoids. J Clin Endocrinol Metab 99:E374-8. doi: https://doi. org/10.1210/jc.2013-2782

34. Capodanno A, Boldrini L, Alì G, Pelliccioni S, Mussi A, Fontanini G (2012) Phosphatidylinositol-3-kinase $\alpha$ catalytic subunit gene somatic mutations in bronchopulmonary neuroendocrine tumours. Oncol Rep 28:1559-66. doi: https:// doi.org/10.3892/or.2012.2017

35. Centonze G, Biganzoli D, Prinzi N, Pusceddu S, Mangogna A, Tamborini E, Perrone F, Busico A, Lagano V, Cattaneo L, Sozzi G, Roz L, Biganzoli E, Milione M (2020) Beyond Traditional Morphological Characterization of Lung Neuroendocrine Neoplasms: In Silico Study of Next-Generation Sequencing Mutations Analysis across the Four World Health Organization Defined Groups. Cancers (Basel) 12:2753. doi: https://doi. org/10.3390/cancers 12102753

36. Scarpa A, Chang DK, Nones K, Corbo V, Patch AM, Bailey P, Lawlor RT, Johns AL, Miller DK, Mafficini A, Rusev B, Scardoni M, Antonello D, Barbi S, Sikora KO, Cingarlini S, Vicentini C, McKay S, Quinn MC, Bruxner TJ, Christ AN, Harliwong I, Idrisoglu S, McLean S, Nourse C, Nourbakhsh E, Wilson PJ, Anderson MJ, Fink JL, Newell F, Waddell N, Holmes O, Kazakoff SH, Leonard C, Wood S, Xu Q, Nagaraj SH, Amato E, Dalai I, Bersani S, Cataldo I, Dei Tos AP, Capelli $\mathrm{P}$, Davì MV, Landoni L, Malpaga A, Miotto M, Whitehall VL, Leggett BA, Harris JL, Harris J, Jones MD, Humphris J, Chantrill LA, Chin V, Nagrial AM, Pajic M, Scarlett CJ, Pinho A, Rooman I, Toon C, Wu J, Pinese M, Cowley M, Barbour A, Mawson A, Humphrey ES, Colvin EK, Chou A, Lovell JA, Jamieson NB, Duthie F, Gingras MC, Fisher WE, Dagg RA, Lau LM, Lee M, Pickett HA, Reddel RR, Samra JS, Kench JG, Merrett ND, Epari K, Nguyen NQ, Zeps N, Falconi M, Simbolo M, Butturini G, Van Buren G, Partelli S, Fassan M; Australian Pancreatic Cancer Genome Initiative, Khanna KK, Gill AJ, Wheeler DA, Gibbs RA, Musgrove EA, Bassi C, Tortora G, Pederzoli P, Pearson JV, Waddell N, Biankin AV, Grimmond SM (2017) Whole-genome landscape of pancreatic neuroendocrine tumours. Nature 543:65-71. doi: https://doi. org/10.1038/nature21063

37. Terra S, Xie H, Boland JM, Mansfield AS, Molina JR, Roden AC (2019) Loss of ATRX expression predicts worse prognosis in pulmonary carcinoid tumors. Hum Pathol 94:78-85. doi: https:// doi.org/10.1016/j.humpath.2019.08.022

38. Wang VE, Young L, Ali S, Miller VA, Urisman A, Wolfe J, Bivona TG, Damato B, Fogh S, Bergsland EK (2017) A Case of Metastatic Atypical Neuroendocrine Tumor with $A L K$ Translocation and Diffuse Brain Metastases. Oncologist 22:768-773. doi: https://doi.org/10.1634/theoncologist.2017-0054

39. Leal JL, Peters G, Szaumkessel M, Leong T, Asadi K, Rivalland G, Do H, Senko C, Mitchell PL, Quing CZ, Dobrovic A, Thapa B, John T (2020) NTRK and ALK rearrangements in malignant pleural mesothelioma, pulmonary neuroendocrine tumours and non-small cell lung cancer. Lung Cancer 146:154159. doi: https://doi.org/10.1016/j.lungcan.2020.05.019 
40. Hoton D, Humblet Y, Libbrecht L (2018) Phenotypic variation of an ALK-positive large-cell neuroendocrine lung carcinoma with carcinoid morphology during treatment with ALK inhibitors. Histopathology 72:707-710. doi: https://doi.org/10.1111/his.13388

41. Rekhtman N, Desmeules P, Litvak AM, Pietanza MC, SantosZabala ML, Ni A, Montecalvo J, Chang JC, Beras A, Preeshagul IR, Sabari JK, Rudin CM, Ladanyi M, Klimstra DS, Travis WD, Lai WC (2019) Stage IV lung carcinoids: spectrum and evolution of proliferation rate, focusing on variants with elevated proliferation indices. Mod Pathol 32:1106-1122. doi: https://doi. org/10.1038/s41379-019-0248-2

42. Cros J, Théou-Anton N, Gounant V, Nicolle R, Reyes C, Humez S, Hescot S, Thomas de Montpréville V, Guyétant $S$, Scoazec JY, Guyard A, de Mestier L, Brosseau S, Mordant P, Castier Y, Gentien D, Ruszniewski P, Zalcman G, Couvelard A, Cazes A (2021) Specific Genomic Alterations in HighGrade Pulmonary Neuroendocrine Tumours with Carcinoid Morphology. Neuroendocrinology 111:158-169. doi: https:// doi.org/10.1159/000506292

43. Toffalorio F, Belloni E, Barberis M, Bucci G, Tizzoni L, Pruneri G, Fumagalli C, Spitaleri G, Catania C, Melotti F, Pelicci PG, Spaggiari L, De Pas T (2014) Gene expression profiling reveals GC and CEACAM1 as new tools in the diagnosis of lung carcinoids. Br J Cancer 110:1244-9. doi: https://doi.org/10.1038/bjc.2014.41

44. Swarts DR, Van Neste L, Henfling ME, Eijkenboom I, Eijk PP, van Velthuysen ML, Vink A, Volante M, Ylstra B, Van Criekinge W, van Engeland M, Ramaekers FC, Speel EJ (2013) An exploration of pathways involved in lung carcinoid progression using gene expression profiling. Carcinogenesis 34:2726-37. doi: https://doi.org/10.1093/carcin/bgt271

45. Swarts DR, Henfling ME, Van Neste L, van Suylen RJ, Dingemans AM, Dinjens WN, Haesevoets A, Rudelius M, Thunnissen E, Volante M, Van Criekinge W, van Engeland M, Ramaekers FC, Speel EJ (2013) CD44 and OTP are strong prognostic markers for pulmonary carcinoids. Clin Cancer Res 19:2197-207. doi: https:// doi.org/10.1158/1078-0432.CCR-12-3078

46. Papaxoinis G, Nonaka D, O'Brien C, Sanderson B, Krysiak P, Mansoor W (2017) Prognostic Significance of CD44 and Orthopedia Homeobox Protein (OTP) Expression in Pulmonary Carcinoid Tumours. Endocr Pathol 28:60-70. doi: https://doi. org/10.1007/s12022-016-9459-y

47. Moonen L, Derks J, Dingemans AM, Speel EJ (2019) Orthopedia Homeobox (OTP) in Pulmonary Neuroendocrine Tumors: The Diagnostic Value and Possible Molecular Interactions. Cancers (Basel) 11:1508. doi: https://doi.org/10.3390/cancers11101508.

48. Simbolo M, Barbi S, Fassan M, Mafficini A, Ali G, Vicentini C, Sperandio N, Corbo V, Rusev B, Mastracci L, Grillo F, Pilotto S, Pelosi G, Pelliccioni S, Lawlor RT, Tortora G, Fontanini G, Volante M, Scarpa A, Bria E (2019) Gene Expression Profiling of Lung Atypical Carcinoids and Large Cell Neuroendocrine Carcinomas Identifies Three Transcriptomic Subtypes with Specific Genomic Alterations. J Thorac Oncol 14:1651-1661. doi: https://doi.org/10.1016/j.jtho.2019.05.003

49. Sazonova O, Manem V, Orain M, Khoshkrood-Mansoori B, Gaudreault N, Desmeules P, Bossé Y, Joubert P (2020) Transcriptomic data helps refining classification of pulmonary carcinoid tumors with increased mitotic counts. Mod Pathol 33:1712-1721. doi: https://doi.org/10.1038/s41379-020-0538-8

50. Pelosi G, Fumagalli C, Trubia M, Sonzogni A, Rekhtman N, Maisonneuve P, Galetta D, Spaggiari L, Veronesi G, Scarpa A, Malpeli G, Viale G (2010) Dual role of RASSF1 as a tumor suppressor and an oncogene in neuroendocrine tumors of the lung. Anticancer Res 30:4269-81. Doi not available

51. Chaussade L, Eymin B, Brambilla E, Gazzeri S (2001) Expression of p15 and p15.5 products in neuroendocrine lung tumours: relationship with $\mathrm{p} 15$ (INK4b) methylation status. Oncogene 20:6587-96. doi: https://doi.org/10.1038/sj.onc.1204798

52. Yang X, Yang L, Dai W, Ye B (2016) Role of p14ARF and p15INK4B promoter methylation in patients with lung cancer: a systematic meta-analysis. Onco Targets Ther 9:6977-6985. doi: https://doi.org/10.2147/OTT.S117161

53. la Torre A, Muscarella LA, Parrella P, Balsamo T, Bisceglia M, Valori VM, la Torre A, Barbano R, Perrella E, Poeta ML, Melchionda G, Merla G, Maiello E, Pellicano R, Fazio VM (2012) Aberrant genes promoter methylation in neural crestderived tumors. Int J Biol Markers 27:e389-94. doi: https://doi. org/10.5301/JBM.2012.9766

54. Sparaneo A, Fabrizio FP, la Torre A, Graziano P, Di Maio M, Fontana A, Bisceglia M, Rossi A, Pizzolitto S, De Maglio G, Tancredi A, Grimaldi F, Balsamo T, Centra F, Manzorra MC, Trombetta D, Pantalone A, Bonfitto A, Maiello E, Fazio VM, Muscarella LA (2019) Effects of KEAP1 Silencing on the Regulation of NRF2 Activity in Neuroendocrine Lung Tumors. Int J Mol Sci 20:2531. doi: https://doi.org/10.3390/ijms20102531

55. Fabrizio FP, Sparaneo A, Centra F, Trombetta D, Storlazzi CT, Graziano P, Maiello E, Fazio VM, Muscarella LA (2019) Methylation Density Pattern of KEAP1 Gene in Lung Cancer Cell Lines Detected by Quantitative Methylation Specific PCR and Pyrosequencing. Int J Mol Sci 20:2697. doi: https://doi. org/10.3390/ijms20112697

56. Shilo K, Wu X, Sharma S, Welliver M, Duan W, VillalonaCalero M, Fukuoka J, Sif S, Baiocchi R, Hitchcock CL, Zhao W, Otterson GA (2013) Cellular localization of protein arginine methyltransferase- 5 correlates with grade of lung tumors. Diagn Pathol 8:201. doi: https://doi.org/10.1186/1746-1596-8-201

57. Findeis-Hosey JJ, Huang J, Li F, Yang Q, McMahon LA, Xu H (2011) High-grade neuroendocrine carcinomas of the lung highly express enhancer of zeste homolog 2, but carcinoids do not. Hum Pathol 42:867-72. doi: https://doi.org/10.1016/j.humpath.2010.09.019

58. Li F, Ye B, Hong L, Xu H, Fishbein MC (2011) Epigenetic modifications of histone $\mathrm{h} 4$ in lung neuroendocrine tumors. Appl Immunohistochem Mol Morphol 19:389-94. doi: https:// doi.org/10.1097/PAI.0b013e3182108e2e

59. Mairinger FD, Ting $S$, Werner R, Walter RF, Hager $T$, Vollbrecht C, Christoph D, Worm K, Mairinger T, SheuGrabellus SY, Theegarten D, Schmid KW, Wohlschlaeger J (2014) Different micro-RNA expression profiles distinguish subtypes of neuroendocrine tumors of the lung: results of a profiling study. Mod Pathol 27:1632-40. doi: https://doi. org/10.1038/modpathol.2014.74

60. Rapa I, Votta A, Felice B, Righi L, Giorcelli J, Scarpa A, Speel EJ, Scagliotti GV, Papotti M, Volante M (2015) Identification of MicroRNAs Differentially Expressed in Lung Carcinoid Subtypes and Progression. Neuroendocrinology 101:246-55. doi: https://doi.org/10.1159/000381454

61. Di Fazio P, Maass M, Roth S, Meyer C, Grups J, Rexin P, Bartsch DK, Kirschbaum A (2017) Expression of hsa-let-7b-5p, hsa-let7f-5p, and hsa-miR-222-3p and their putative targets HMGA2 and CDKN1B in typical and atypical carcinoid tumors of the lung. Tumour Biol 39:1010428317728417. doi: https://doi. org/10.1177/1010428317728417

62. Yoshimoto T, Motoi N, Yamamoto N, Nagano H, Ushijima M, Matsuura M, Okumura S, Yamaguchi T, Fukayama M, Ishikawa Y (2018) Pulmonary Carcinoids and Low-Grade Gastrointestinal Neuroendocrine Tumors Show Common MicroRNA Expression Profiles, Different from Adenocarcinomas and Small Cell Carcinomas. Neuroendocrinology 106:47-57. doi: https://doi. org/10.1159/000461582

63. Narayanan D, Mandal R, Hardin H, Chanana V, Schwalbe M, Rosenbaum J, Buehler D, Lloyd RV (2020) Long Non-coding 
RNAs in Pulmonary Neuroendocrine Neoplasms. Endocr Pathol 31:254-263. doi: https://doi.org/10.1007/s12022-020-09626-1

64. Rieker RJ, Aulmann S, Penzel R, Schnabel PA, Blaeker H, Esposito I, Morresi-Hauf A, Otto HF, Hecker E, Dienemann H, Schirmacher P, Mechtersheimer G (2005) Chromosomal imbalances in sporadic neuroendocrine tumours of the thymus. Cancer Lett 223:169-74. doi: https://doi.org/10.1016/j.canlet.2004.10.027

65. Pan CC, Jong YJ, Chen YJ (2005) Comparative genomic hybridization analysis of thymic neuroendocrine tumors. Mod Pathol 18:358-64. doi: https://doi.org/10.1038/modpathol.3800246

66. Ströbel P, Zettl A, Shilo K, Chuang WY, Nicholson AG, Matsuno Y, Gal A, Laeng RH, Engel P, Capella C, Marino M, Chan JK, Rosenwald A, Travis W, Franks TJ, Ellenberger D, Schaefer IM, Marx A (2014) Tumor genetics and survival of thymic neuroendocrine neoplasms: a multi-institutional clinicopathologic study. Genes Chromosomes Cancer 53:73849. doi: https://doi.org/10.1002/gcc.22183

67. Kidd M, Drozdov I, Modlin I (2015) Blood and tissue neuroendocrine tumor gene cluster analysis correlate, define hallmarks and predict disease status. Endocr Relat Cancer 22:561-75. doi: https://doi.org/10.1530/ERC-15-0092

68. Teh BT, Zedenius J, Kytölä S, Skogseid B, Trotter J, Choplin H, Twigg S, Farnebo F, Giraud S, Cameron D, Robinson B, Calender A, Larsson C, Salmela P (1998) Thymic carcinoids in multiple endocrine neoplasia type 1. Ann Surg 228:99-105. doi: https://doi.org/10.1097/00000658-199807000-00015

69. Gibril F, Chen YJ, Schrump DS, Vortmeyer A, Zhuang Z, Lubensky IA, Reynolds JC, Louie A, Entsuah LK, Huang K, Asgharian B, Jensen RT (2003) Prospective study of thymic carcinoids in patients with multiple endocrine neoplasia type 1 . $\mathrm{J}$ Clin Endocrinol Metab 88:1066-81. doi: https://doi.org/10.1210/ jc.2002-021314

70. Leotlela PD, Jauch A, Holtgreve-Grez H, Thakker RV (2003) Genetics of neuroendocrine and carcinoid tumours. Endocr Relat Cancer 10:437-50. doi: https://doi.org/10.1677/erc.0.0100437

71. Fujii T, Kawai T, Saito K, Hishima T, Hayashi Y, Imura J, Hironaka M, Hosoya Y, Koike M, Fukayama M (1999) MEN1 gene mutations in sporadic neuroendocrine tumors of foregut derivation. Pathol Int 49:968-73. doi: https://doi.org/10. 1046/j.1440-1827.1999.00971.x

72. Liu RX, Wang WQ, Ye L, Bi YF, Fang H, Cui B, Zhou WW, Dai M, Zhang J, Li XY, Ning G (2010) p21-activated kinase 3 is overexpressed in thymic neuroendocrine tumors (carcinoids) with ectopic ACTH syndrome and participates in cell migration. Endocrine 38:38-47. doi: https://doi.org/10.1007/s12020-010-9324-6

73. Bi YF, Liu RX, Ye L, Fang H, Li XY, Wang WQ, Zhang J, Wang KK, Jiang L, Su TW, Chen ZY, Ning G (2009) Gene expression profiles of thymic neuroendocrine tumors (carcinoids) with ectopic ACTH syndrome reveal novel molecular mechanism. Endocr Relat Cancer 16:1273-82. doi: https://doi.org/10.1677/ERC-08-0325

74. Mete O, Hannah-Shmouni F, Kim R, Stratakis CA. Inherited Neuroendocrine Neoplasms. In: Asa SL, La Rosa S, Mete O. (eds) The Spectrum of Neuroendocrine Neoplasia. Springer, Cham. 2021, pp: 409-459

75. Asa SL, Ezzat S, Mete O (2018) The Diagnosis and Clinical Significance of Paragangliomas in Unusual Locations. J Clin Med 7:280. doi: https://doi.org/10.3390/jcm7090280

76. Kimura N. Dopamine $\beta$-hydroxylase: An Essential and Optimal Immunohistochemical Marker for Pheochromocytoma and Sympathetic Paraganglioma (2021) Endocr Pathol. Epub ahead of print. doi: https://doi.org/10.1007/s12022-020-09655-w.

77. Duan K, Mete O (2016) Algorithmic approach to neuroendocrine tumors in targeted biopsies: Practical applications of immunohistochemical markers. Cancer Cytopathol 124:871-884. doi: https://doi.org/10.1002/cncy.21765
78. Szybowska M, Mete O, Weber E, Silver J, Kim RH (2019) Neuroendocrine Neoplasms Associated with Germline Pathogenic Variants in the Homologous Recombination Pathway. Endocr Pathol 30:237-245. doi: https://doi.org/10.1007/s12022-019-9569-4

79. Thakker RV (2014) Multiple endocrine neoplasia type 1 (MEN1) and type 4 (MEN4). Mol Cell Endocrinol 386:2-15. doi: https:// doi.org/10.1016/j.mce.2013.08.002

80. Ye L, Wang W, Ospina NS, Jiang L, Christakis I, Lu J, Zhou Y, Zhu W, Cao Y, Wang S, Perrier ND, Young WF Jr, Ning G, Wang W (2017) Clinical features and prognosis of thymic neuroendocrine tumours associated with multiple endocrine neoplasia type 1: A single-centre study, systematic review and meta-analysis. Clin Endocrinol (Oxf) 87:706-716. doi: https:// doi.org/10.1111/cen. 13480

81. Bartsch DK, Albers MB, Lopez CL, Apitzsch JC, Walthers EM, Fink L, Fendrich V, Slater EP, Waldmann J, Anlauf M (2016) Bronchopulmonary Neuroendocrine Neoplasms and Their Precursor Lesions in Multiple Endocrine Neoplasia Type 1. Neuroendocrinology 103:240-7. doi: https://doi. org/10.1159/000435921

82. Christakis I, Qiu W, Silva Figueroa AM, Hyde S, Cote GJ, Busaidy NL, Williams M, Grubbs E, Lee JE, Perrier ND (2016) Clinical Features, Treatments, and Outcomes of Patients with Thymic Carcinoids and Multiple Endocrine Neoplasia Type 1 Syndrome at MD Anderson Cancer Center. Horm Cancer 7:27987. doi: https://doi.org/10.1007/s12672-016-0269-y

83. Pieterman CR, Conemans EB, Dreijerink KM, de Laat JM, Timmers HT, Vriens MR, Valk GD (2014) Thoracic and duodenopancreatic neuroendocrine tumors in multiple endocrine neoplasia type 1: natural history and function of menin in tumorigenesis. Endocr Relat Cancer 21:R121-42. doi: https:// doi.org/10.1530/ERC-13-0482

84. Sachithanandan N, Harle RA, Burgess JR (2005) Bronchopulmonary carcinoid in multiple endocrine neoplasia type 1. Cancer 103:509-15. doi: https://doi.org/10.1002/cncr.20825

85. Murat A, Heymann MF, Bernat S, Dupas B, Delajartre AY, Calender A, Despins P, Michaud JL, Giraud S, Le Bodic MF, Charbonnel B (1997) Tumeurs neuro-endocrines thymiques et bronchiques au cours des néoplasies endocrines multiples de type 1. GENEM1 [Thymic and bronchial neuroendocrine tumors in multiple endocrine neoplasia type 1. GENEM1]. Presse Med 26:1616-21.

86. de Laat JM, Pieterman CR, van den Broek MF, Twisk JW, Hermus AR, Dekkers OM, de Herder WW, van der HorstSchrivers AN, Drent ML, Bisschop PH, Havekes B, Vriens MR, Valk GD (2014) Natural course and survival of neuroendocrine tumors of thymus and lung in MEN1 patients. J Clin Endocrinol Metab 99:3325-33. doi: https://doi.org/10.1210/jc.2014-1560

87. Thakker RV, Newey PJ, Walls GV, Bilezikian J, Dralle H, Ebeling PR, Melmed S, Sakurai A, Tonelli F, Brandi ML; Endocrine Society (2012) Clinical practice guidelines for multiple endocrine neoplasia type 1 (MEN1). J Clin Endocrinol Metab 97:2990-3011. doi: https://doi.org/10.1210/jc.2012-1230

88. Duan K, Mete O (2017) Hereditary Endocrine Tumor Syndromes: The Clinical and Predictive Role of Molecular Histopathology. AJSP: Reviews \& Reports 22: 246-268. Doi not available

89. Frederiksen A, Rossing M, Hermann P, Ejersted C, Thakker RV, Frost M (2019) Clinical Features of Multiple Endocrine Neoplasia Type 4: Novel Pathogenic Variant and Review of Published Cases. J Clin Endocrinol Metab 104:3637-3646. doi: https://doi.org/10.1210/jc.2019-00082

90. Larouche V, Akirov A, Thain E, Kim RH, Ezzat S (2019) Co-occurrence of breast cancer and neuroendocrine tumours: New genetic insights beyond Multiple Endocrine Neoplasia syndromes. Endocrinol Diabetes Metab 2:e0092. doi: https:// doi.org/10.1002/edm2.92 
91. Young LR, Deutsch GH, Bokulic RE, Brody AS, Nogee LM (2013) A mutation in TTF1/NKX2.1 is associated with familial neuroendocrine cell hyperplasia of infancy. Chest 144:11991206. doi: https://doi.org/10.1378/chest.13-0811

92. Nevel RJ, Garnett ET, Worrell JA, Morton RL, Nogee LM, Blackwell TS, Young LR (2016) Persistent Lung Disease in Adults with NKX2.1 Mutation and Familial Neuroendocrine Cell Hyperplasia of Infancy. Ann Am Thorac Soc 13:1299-304. doi: https://doi.org/10.1513/AnnalsATS.201603-155BC

93. Hassan WA, Udaka N, Ueda A, Ando Y, Ito T (2015) Neoplastic lesions in CADASIL syndrome: report of an autopsied Japanese case. Int J Clin Exp Pathol 8:7533-9.

94. Pedro J, Cunha FM, Neto V, Hespanhol V, Martins DF, Guimarães S, Varela A, Carvalho D (2020) Coexistence of DIPNECH and carotid body paraganglioma: is it just a coincidence? Endocrinol Diabetes Metab Case Rep 2020:EDM19-0141. doi: https://doi. org/10.1530/EDM-19-0141.

95. Caplin ME, Baudin E, Ferolla P, Filosso P, Garcia-Yuste M, Lim E, Oberg K, Pelosi G, Perren A, Rossi RE, Travis WD; ENETS consensus conference participants (2015) Pulmonary neuroendocrine (carcinoid) tumors: European Neuroendocrine Tumor Society expert consensus and recommendations for best practice for typical and atypical pulmonary carcinoids. Ann Oncol 26:1604-20. doi: https://doi.org/10.1093/annonc/mdv041

96. Dasari A, Bergsland EK, Benson AB, Cai B, Huynh L, Totev T, Shea J, Duh MS, Neary MP, Dagohoy CG, Shih BE, Maurer VE, Chan J, Kulke MH (2019) Treatment Patterns and Clinical Outcomes in Advanced Lung Neuroendocrine Tumors in RealWorld Settings: A Multicenter Retrospective Chart Review Study. Oncologist 24:1066-1075. doi: https://doi.org/10.1634/ theoncologist.2018-0520

97. Vesterinen T, Leijon H, Mustonen H, Remes S, Knuuttila A, Salmenkivi K, Vainio P, Arola J, Haglund C (2019) Somatostatin Receptor Expression Is Associated With Metastasis and Patient Outcome in Pulmonary Carcinoid Tumors. J Clin Endocrinol Metab 104:2083-2093. doi: https://doi.org/10.1210/ jc.2018-01931

98. Sullivan I, Le Teuff G, Guigay J, Caramella C, Berdelou A, Leboulleux S, Déandréis D, Hadoux J, Ducreux M, Duvillard P, Adam J, Scoazec JY, Baudin E, Planchard D (2017) Antitumour activity of somatostatin analogues in sporadic, progressive, metastatic pulmonary carcinoids. Eur J Cancer 75:259-267. doi: https://doi.org/10.1016/j.ejca.2016.11.034

99. de Mestier L, Couvelard A, Blazevic A, Hentic O, de Herder WW, Rebours V, Paradis V, Ruszniewski P, Hofland LJ, Cros J (2020) Critical appraisal of MGMT in digestive NET treated with alkylating agents. Endocr Relat Cancer 27:R391-R405. doi: https://doi.org/10.1530/ERC-20-0227

100. Vatrano S, Giorcelli J, Votta A, Capone G, Izzo S, Gatti G, Righi L, Napoli F, Scagliotti G, Papotti M, Volante M, Rapa
I (2020) Multiple Assays to Determine MethylguanineMethyltransferase Status in Lung Carcinoids and Correlation with Clinical and Pathological Features. Neuroendocrinology 110:1-9. doi: https://doi.org/10.1159/000500158

101. Moris D, Ntanasis-Stathopoulos I, Tsilimigras DI, Adam MA, Yang C-FJ, Harpole D, Theocharis S (2018) Insights into Novel Prognostic and Possible Predictive Biomarkers of Lung Neuroendocrine Tumors. Cancer Genomics Proteomics 15:153163. doi: https://doi.org/10.21873/cgp.20073

102. Xie H, Boland JM, Maleszewski JJ, Aubry MC, Yi ES, Jenkins SM, Koepplin JW, Terra SBSP, Mansfield AS, Roden AC (2019) Expression of delta-like protein 3 is reproducibly present in a subset of small cell lung carcinomas and pulmonary carcinoid tumors. Lung Cancer 135:73-79. doi: https://doi.org/10.1016/j. lungcan.2019.07.016

103. Samartzis EP, Gutsche K, Dedes KJ, Fink D, Stucki M, Imesch P (2014) Loss of ARID1A expression sensitizes cancer cells to PI3K- and AKT-inhibition. Oncotarget 5:5295-303. doi: https:// doi.org/10.18632/oncotarget.2092

104. Bitler BG, Aird KM, Garipov A, Li H, Amatangelo M, Kossenkov AV, Schultz DC, Liu Q, Shih IeM, Conejo-Garcia JR, Speicher DW, Zhang R (2015) Synthetic lethality by targeting EZH2 methyltransferase activity in ARID1A-mutated cancers. Nat Med 21:231-8. doi: https://doi.org/10.1038/nm.3799

105. Williamson CT, Miller R, Pemberton HN, Jones SE, Campbell J, Konde A, Badham N, Rafiq R, Brough R, Gulati A, Ryan CJ, Francis J, Vermulen PB, Reynolds AR, Reaper PM, Pollard JR, Ashworth A, Lord CJ (2016) ATR inhibitors as a synthetic lethal therapy for tumours deficient in ARID1A. Nat Commun 7:13837. doi: https://doi.org/10.1038/ncomms13837

106. Shen J, Ju Z, Zhao W, Wang L, Peng Y, Ge Z, Nagel ZD, Zou J, Wang C, Kapoor P, Ma X, Ma D, Liang J, Song S, Liu J, Samson LD, Ajani JA, Li GM, Liang H, Shen X, Mills GB, Peng G (2018) ARID1A deficiency promotes mutability and potentiates therapeutic antitumor immunity unleashed by immune checkpoint blockade. Nat Med 24:556-562. doi: https://doi.org/10.1038/ s41591-018-0012-Z

107. Basturk O, Yang Z, Tang LH, Hruban RH, Adsay V, McCall CM, Krasinskas AM, Jang KT, Frankel WL, Balci S, Sigel C, Klimstra DS (2015) The high-grade (WHO G3) pancreatic neuroendocrine tumor category is morphologically and biologically heterogenous and includes both well differentiated and poorly differentiated neoplasms. Am J Surg Pathol 39:683-90. doi: https://doi. org/10.1097/PAS.0000000000000408

Publisher's Note Springer Nature remains neutral with regard to jurisdictional claims in published maps and institutional affiliations. 